\title{
Pemrosessan Sinyal Waktu Diskrit Menggunakan Compressive Sensing Berdasarkan Algoritma Pemulihan $L_{l}$
}

\author{
${ }^{1}$ Umi Murdika, ${ }^{2}$ Lukmanul Hakim \\ Jurusan Teknik Elektro Universitas Lampung \\ ${ }^{1}$ umi.murdika@eng, unila, ac, id \\ ${ }^{2}$ plgsekipdeng.unila.ac.id
}

\begin{abstract}
Abstrak, - Metode Compressive Sensing merupakan metode yang banyak diaplikasikan pada pemrosesan sinyal. Kemampuan dan keunggulan metode ini mampu merekonstruksi sinyal dengan masukan yang terbatas. Makalah ini bertujuan menggunakan metode Compressive Sensing dalam mengolah sinyal digital waktu diskrit. Keutaman dari metode CS ini adalah memberikan perkiraan sinyal asli dari sejumlah kecil pengukuran linier inkoheren dengan memanfaatkan sifat kejarangannya Penyelesaian dengan metode Compressive Sensing menggunakan pendekatan sinyal sebagai kombinasi linier dari fungsi dasar yang merupakan matriks koefisien jarang (sparse matrix). Pemulihan sinyal dilakukan dengan meminimalkan $\ell 1$ norm dari persamaan sistem tersebut. Makalah ini menunjukkan bahwa dengan metode yang diterapkan pada pemrosessan sinyal, hanya dengan jumlah sinyal yang terbatas dapat dikembalikan lagi mendekati dengan sinyal aslinya. Dengan perbedaan antara sinyal hasil pemulihan dengan sinyal asli yang cukup kecil.
\end{abstract}

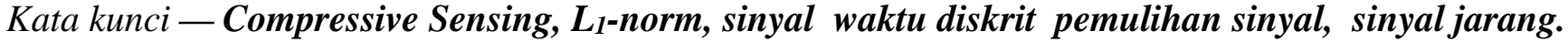

Abstract - Compressive Sensing method is a method that is widely applied to signal processing. The ability and superiority of this method is able to reconstruct signals with limited input. This paper aims to use the Compressive Sensing method in processing discrete time signals. The advantage of this CS method is to provide an original signal estimate from a small number of incoherent linear measurements by utilizing the sparsity properties. Solution using the Compressive Sensing method uses the signal approach as a linear combination of the basic functions which are sparse matrices. Signal recovery is done by minimizing $L_{1}$-norm of the system equation. This paper shows that with the method applied to signal processing, a limited number of measurement signals can be returned close to the original signal. With the difference between the recovery signal and the original signal which is quite small.

Keyword - Compressive Sensing, $L_{1}$-norm, discrete time signals, recovery signal, sparse signal.

\section{PENDAHULUAN}

Compressive Sensing atau CS merupakan metode yang tengah mengemuka saat ini dalam bidang pemrosesan sinyal yang memungkinkan mengakuissi sinyal dengan jumlah sampel yang terbatas setidaknya dibawah dari jumlah yang disyaratkan oleh Shannon/Nyquist. Metode Compressive Sensing ini digadang dapat memulihkan sinyal yang memiliki sampel terbatas dengan mensyaratkan sinyal tersebut dengan beberapa ketentuan yaitu sinyal pengukuran bersifat jarang (sparse) dan dan basis yang inkoheren. Berdasarkan aturan yang telah dikemukakan Nyquist bahwa untuk mendapatkan atau memulihkan kembali sinyal informasi haruslah dilakukan pencuplikan (sampling) dengan paling sedikit 2 kali nilai frekuensi sinyal. Sinyal pengukuran dengan frekuensi tertinggi $50 \mathrm{~Hz}$ berarti baru dapat dipulihkan dengan mensamplingnya pada frekuensi paling sedikit $100 \mathrm{~Hz}$. Disinilah yang menjadi keunggulan dari metode Compressive Sensing yang mengizinkan menggunakan lebih sedikit sampel pengukuran namun tetap mampu menghasilkan pemulihan sinyal secara baik atau lebih baik. Keunggulan lain yang dapat diperoleh dari sini adalah data yang terkompresi tidak membutuhkan ruang penyimpanan yang besar, dengan jumlah peralatan yang lebih sedikit misalnya penggunaan sensor.

Adakalanya jumlah pengukuran yang terbatas yang dapat diperoleh, misalnya pada pengolahan citra kesehatan yaitu pada scan Magnetic Resonance Imaging /MRI dimana waktu pemindaian untuk mendapatkan data 
pengukuran berbanding linier dengan jumlah data yang nantinya menentukan keakuratan citra yang akan dihasilkan.

Keterbatasan pengukuran akan memberatkan bila mengunakan teorema Shannon/Nyquist yang mensyaratkan sampel dua kali frekuensi maksimum sinyal pengukuran. Istilah Compressive Sensing /CS pertama kali digagas oleh Candes et al. [1], dan Donoho [2], dan [3], yang menyatakan bahwa sinyal pengukuran yang terbatas dapat dipulihkan kembali dengan baik menggunakan metode yang mereka usulkan dengan dengan syarat sinyal tersebut harus dalam kondisi jarang (sparse). Tujuan utama dari metode $C S$ ini memberikan perkiraan sinyal asli dari sejumlah kecil pengukuran linier yang inkoheren dengan mengekploitasi sifat kejarangannya (sparsity) [6,7].

Sinyal jarang atau sparse merupakan istilah yang digunakan pada $C S$, yang secara matematis menyatakan kumpulan data jarang adalah yang memiliki jumlah nilai yang bukan-nol yang sedikit. Dengan kata lain data tersebut kebanyakan mengandung nilai nol dan hanya beberapa data yang bukan nol memiliki nilai penting sebagai pembawa informasi.

Kadangkala sinyal yang ingin diamati bukan merupakan sinyal yang jarang dalam domain pengukuran yang ada, misalnya sinyal yang merupakan gabungan dan sejumlah kecil sinyal sinusoidal. Pada domain waktu fungsi sinusoidal tersebut tidaklah bernilai jarang, karenanya kita mengamatinya pada domain frekuensi yang tentu saja akan ditampilkan hanya dengan dua puncak frekuensi saja. Karenanya untuk melakukan proses pemulihan dalam domain jarang, maka harus secara jelas kita memahami tentang tansformasi tersebut.

Asumsi dasar pada penerapan CS adalah pada aplikasi nyata sinyal pengukuran memiliki representasi singkat dalam domain transformasi tertentu dimana hanya sedikit komponen yang penting, sementara sisanya adalah nilai nol atau bisa diabaikan.

Pada teori Compressive sensing ini tidak hanya merencanakan akuisisi sinyal, yang dilakukan juga kemungkinan-kemungkinan pemulihan dari sinyal tersebut dengan menggunakan algoritma yang berbeda [8-10]. Secara garis besar pendekatan untuk pemulihan sinyal Compressive sensing dibagi menjadi dua pendekatan yaitu convex optimization misalnya basis pursuit [8-10], dan algoritma greedy misalnya matching pursuit [11]. Didasarkan tinjauan beberapa algoritma tersebut pada [12], dinyatakan algotritma convex memberikan keakuratan pemulihan sinyal yang paling baik dibandingkan dengan beberapa algoritma lainnya.

Pada makalah ini dilakukan suatu studi mengaplikasikan konsep Compressive Sensing dengan menggunakan pendekatan transformasi yang berbeda. Seperti diketahui bahwa transformasi merupakan bagian penting dalam CS sebagai suatu cara yang secara konsep diterapkan untuk memperoleh sinyal jarang (sparsity) yang merupakan bagian penting yang disyaratkan CS. Banyak metode transformasi untuk mewakili sinyal dalam basis sparsity diusulkan baru-baru ini, misalnya yang umumnya dikenal adalah fast Fourier Transform(FFT), Discrete Cosine Transform(DCT) dan wavelet Transform $(D W T)$ dan lain lain. Namun pada saat ini hanya akan mencoba mengaplikasikan Discrete Fourier transform dan Discrete Cosine transform, sedangkan algoritma pemulihan yang akan diadopsi adalah algorima $L_{1^{-}}$norm. Makalah ini disusun menjadi beberapa bagian, meliputi bagian 2 yang merupakan pemaparan konsep Compressive Sensing dan metode pemulihannya, kemudian pada bagian 3 dibahas tentang pemulihan sinyal menggunakan Pendekatan algoritma $L_{1}$ Minimization, dan pada 4 adalah Pengolahan sinyal diskrit menerapkan Compressive Sensing menggunakan metode transformasi yang berbeda, dan pada 5 merupakan hasil simulasi dengan indikator error.

\section{COMPRESSIVE SENSING}

Anggaplah bahwa suatu sinyal s merupakan sinyal waktu diskrit yang dinyatakan sebagai vektor dengan ukuran Nx1.Asumsikan bahwa sinyal $\mathrm{x}$ menunjukkan sifat jarang (sparsity) pada basis orthonormal tertentu yang didefinisikan menggunakan basis $\Psi$. 
Maka sinyal $\mathrm{x}$ dapat dinyatakan sebagai jumlah linier dari vektor basis, $\Psi_{1}, \Psi_{2}, \Psi_{3}, \ldots$. $\Psi_{\mathrm{N}}$ :

$$
x(n)=\sum_{1=1}^{N} \psi_{i}(n) s_{i}
$$

$\mathrm{s}_{\mathrm{i}}$ menunjukkan koefisien vektor $\mathrm{s}$, sehingga dapat dinyatakan sebagai;

$$
\boldsymbol{x}=\boldsymbol{\psi s}
$$

Dimana $\Psi$ menyatakan matrik transformasi dengan kolom adalah vektor basis. Nilai basis $\Psi$ dapat diperoleh menggunakan koefisien matrik Discrete Cosine transform, koefisien matrik fourier, matrix koefisien wevelet dan lain sebagainya. Apabila nilai koefisien $\mathrm{K}$ dengan $(\mathrm{K}<\mathrm{N})$ domain transformasi pengukuran nilainya sebagian besar bernilai nol, maka sinyal dapat dinyatakan sebagai $K$ sparse pada domain transformasi.

Compressive sensing mengunakan sinyal untuk pemulihan dari sejumlah kecil pengukuran $\mathrm{M}$, dengan mempergunakan sinyal jarang (sparse) dari suatu domain transformasi. Pengurangan frekuensi sampling menggunakan $C S$ sangat memungkinkan untuk kasus sinyal jarang yang dinyatakan oleh sebagian kecil koefisien penting pada suatu basis transformasi tertentu. Akuisisi sinyal yang semula telah didefinisikan menjadi penting agar informasi sinyal tetap terjaga meskipun terjadi pengurangan dimensi $(\mathrm{M}<\mathrm{N})$. Jika y menunjukkan vektor pengukuran, maka persamaan:

$$
y_{M x 1}=\phi_{M x N} x_{N x 1}
$$

Dimana $\Phi$ menunjukkan matrik pengukuran. Berdasarkan persamaan (2) dan (3), maka akan diperoleh:

$$
y=\phi x=\phi \psi s=A s
$$

Matrik A yang diperoleh merupakan matrik Compressive Sensing. Untuk memulihkan sinyal s membutuhkan penyelesaian sistem yang terdiri dari $\mathrm{M}$ persamaan dengan $\mathrm{N}$ jumlah variabel yang tidak diketahui. Sistem ini sulit ditentukan dan memiliki solusi yang tak terbatas. Karenanya penggunaan algoritma optimasi perlu diterapkan untuk mendapatkan hasil yang paling optimal.

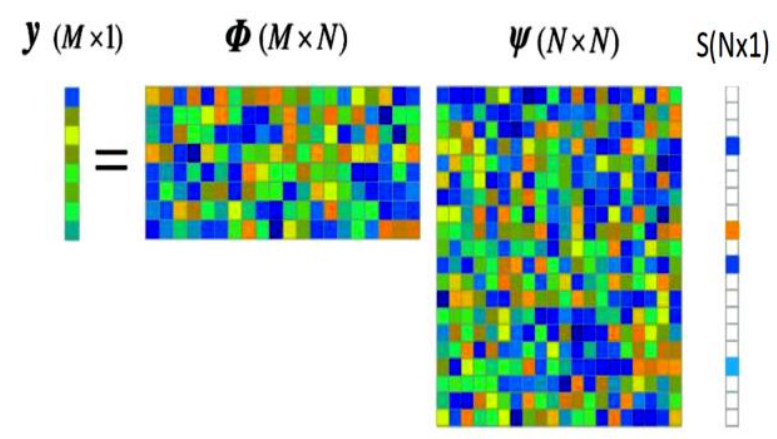

Gbr.1 Proses CS dengan matrik pengukuran $\Phi$ dan matrik trasnformasi $\Psi[10]$

Prosedur pengukuran harus memenuhi kondisi tertentu, untuk mendapatkan keberhasilan pemulihan sinyal. Pertama matrik pengukuran $\Phi$ haruslah inkoheren dengan matrik basis $\Psi$. Koherensi antara kedua matrik pengukuran tersebut adalah mengukur hubungan korelasi tertinggi antara kedua elemen matrik. Apabila tidak terdapat korelasi yang tinggi, maka dinyatakan sebagai matrik yang inkoheren. Pengukuran korelasi kedua matrik basis tersebut didefinisikan sebagai;

$$
\mu(\Phi, \Psi)=\sqrt{N} \max _{k \geq 1, j \leq N}\left|\left(\phi_{k}, \psi_{j}\right)\right|
$$

Dimana $\mathrm{N}$ adalah panjang sinyal, $\Phi_{\mathrm{k}}$ vektor baris dan $\Psi_{\mathrm{j}}$ merupakan vektor kolom dari masing masing matrik basis $\Phi$ dan matrik basis $\Psi$. Nilai koherensi berada pada kisaran nilai:

$$
1 \leq \mu(\phi, \psi) \leq \sqrt{N}
$$

Nilai koheren yang terendah adalah pada $\mu(\Phi, \Psi)=1$, yang artinya tingkat inkoheren antara matrik basis $\Phi$ dan matrik basis $\Psi$ adalah tinggi. Inkoheren dibutuhkan untuk mendapatkan informasi maksimum dari jumlah minimum pengukuran. Apabila tingkat inkoheren telah memenuhi syarat, maka jumlah pengukuran yang diperlukan dapat diperoleh dengan nilai;

$$
M \geq c K \log (N / K)
$$

Nilai c adalah konstanta. Kondisi inkoheren yang disebutkan diatas dihubungkan pada Restricted Isometry Property (RIP) pada 
matrik A yang merupakan basis proyeksi dan basis jarang (sparse). Maksud dari sifat RIP ini artinya bahwa subset dari matrik kolom $\mathrm{A}=\Phi \Psi$ harusnya mendekati hubungan saling orthogonal. RIP dapat didefinisikan sebagai:

$$
\begin{aligned}
\left(1-\delta_{K}\right)\|s\|_{\ell_{2}}^{2} & \leq\|A s\|_{\ell_{2}}^{2} \\
& \leq\left(1+\delta_{K}\right)\|s\|_{\ell_{2}}^{2}
\end{aligned}
$$

Dimana $\delta_{K}$ adalah konstanta sifat isometri. Probabilitas atau kemungkinan sinyal dapat dipulihkan kembali jika kedua sifat inkoheren dan RIP terpenuhi.

\section{PEMULIHAN SINYAL MENGGUNAKAN PENDEKATAN $L_{l}$ MINIMIZATION}

Pemulihan sinyal artinya adalah memulihkan vektor $\mathrm{x}$ dari pengukuran $\mathrm{y}=\mathrm{As}$. Permasalahan ini merupakan penyelesaian masalah yang tidak terdefinisi dari suatu persamaan linier. Untuk memulihkan sinyal $\mathrm{x}$ membutuhkan penyelesaian sistem yang terdiri dari $\mathrm{M}$ persamaan dengan $\mathrm{N}$ jumlah variabel yang tidak diketahui. Sistem ini tentu saja akan memiliki solusi yang tak terbatas. Karenanya untuk memulihkan sinyal $\mathrm{x}$ tersebut pendekatan yang dilakukan adalah penggunaan algoritma optimasi $L_{1}$ Minimization atau basis pursuit yang telah diterapkan sebelumnya oleh Candes, Romberg dan Tao [1] [5], sehingga bisa diperoleh hasil yang paling optimal. Permasalahan optimasi didefinisikan dalam keadaan ketika s jarang, masalahnya dapat dikurangi menjadi minimalisasi berikut:

$$
\begin{gathered}
\min \|s\|_{0} \\
\text { s.t. } \quad y=A s
\end{gathered}
$$

Masalah pemulihan sinyal didefinisikan sebagai pemulihan vektor s dari pemgukuran. $L_{1}$-minimization membutuhkan pencarian lengkap pada semua kondisi kejarangan matrik yang mungkin yang secara komputasi sulit dilakukan. Oleh karena itu $L_{0}$-minimization digantikan oleh convex $L_{1}$-minimization, yang akan menghasilkan matrik jarang dengan kemungkinan tinggi dengan syarat matrik pengukuran memenuhi kondisi sebelumnya,
Masalah Lo-minimization dapat didefinisikan sebagai berikut:

$$
\text { s.t. } \quad y=A s
$$

Dan pemecahan masalah $L_{1}$ ini disebut juga sebagai basis pursuit.

\section{PENGOLAHAN SINYAL DISKRIT MENGGUNAKAN CS}

Misalkan kita memiliki sinyal $\mathrm{x}$, yang merupakan sinyal dengan panjang $\mathrm{N}$ dalam domain waktu, sehingga dengan mudah kita dapat menentukan $\mathrm{N}$ pengukuran. Namun bagaimana jika kita hanya menggunakan sedikit jumlah pengukuran $\mathrm{K}$ yaitu $\mathrm{K}<\mathrm{N}$. Disini dapat dikatakan bahwa sinyal $\mathrm{x}$ yang kita gunakan dalam domain waktu sudah merupakan sinyal yang jarang (sparse). Oleh karena itu matrik $\Psi$ hanyalah suatu matrik identitas.

Dengan menggunakan vektor y untuk mewakili pengukuran $\mathrm{K}$, penting untuk dicatat bahwa satu pengukuran tidak selalu sesuai dengan nilai input tunggal, karena sistem kehidupan nyata pengukuran tidak selalu dilakukan dalam satu file, secara linier.

Untuk mencari nilai y, kita menggunakan A. Secara sederhana dinyatakan sebagai $\mathrm{y}=$ Ax, dimana A adalah sensing matrik. Untuk mendapatkan nilai $\mathrm{x}$ dari y dapat dilakukan melalui suatu pengukuran random, atau menggunakan transformasi atau kombinasi keduanya. Jika $\mathrm{x}$ adalah sinyal sparse, yang artinya hanya sedikit nilai yang penting. maka jika secara acak kita menyimpan beberapa nilai, maka kita akan kehilangan yang kita butuhkan, karena kita tidak tahu dimana lokasi nilai penting tersebut berada sebelumnya. Dengan menggunakan pendekatan variabel Gausian Random pada matrik sensing A, maka kemungkinan untuk kehilangan data menjadi kecil.

Apabila sinyal yang akan diamati merupakan sinyal yang tidak jarang (sparse) dalam domain pengukuran yang ada, misalnya sinyal yang merupakan gabungan dari sejumlah kecil sinyal sinusoidal. 
Pada domain waktu sinyal sinusoidal tersebut tidaklah bernilai jarang, karenanya kita mengamatinya pada domain frekuensi yang tentu saja akan ditampilkan hanya dengan dua puncak frekuensi saja. Untuk melakukan proses pemulihan dalam domain jarang, maka harus secara jelas kita memahami tentang tansformasi yang digunakan tersebut. Asumsi dasar pada CS memiliki representasi dalam domain transformasi tertentu dimana hanya sedikit komponen yang penting, sementara sisanya adalah nilai nol atau bisa diabaikan.

Untuk mengolahnya menggunakan $C S$, seperti yang telah disebutkan sebelumnya bahwa sinyal haruslah bersifat jarang, maka kehadiran basis $\Psi$ merupakan cara yang dilakukan secara matematika untuk memperoleh sinyal jarang tersebut. Sebagai contoh dari skenario CS ini, misalnya sinyal A yang multi komponen yang terdiri dari $\mathrm{K}$ sinyal sinusoid yang jarang pada domain transformasi DFT,

$$
x(n)=\sum_{i=1}^{K} A_{i} e^{j 2 \pi f_{i} n / N}
$$

Dimana tingkat kejarangannya adalah $\mathrm{K}<<\mathrm{N}$, dimana $\mathrm{N}$ merupakan panjang sinyal, sedangkan $A_{i}$ dan $f_{i}$ menunjukkan amplitudo dan frekuensi dari komponen komponen sinyal. Karena $\mathrm{x}$ adalah sinyal jarang pada domain DFT, maka dapat dinyatakan sebagai:

$$
x=\psi F=\gamma^{-1} F
$$

Dimana F adalah vektor koefisien DFT dimana kebanyakan koefisien $\mathrm{K}$ adalah bukannol, sedangkan $\gamma^{-1}$ merupakan invers matrik transformasi fourier yang berukuran $\mathrm{NxN}$.

Jika x sebagai sinyal yang kita aplikasikan $C S$, maka hanya pengukuran random $\mathrm{y} \subset \mathrm{x}$ tersedia dan dapat dinyatakan sebagai sekumpulan posisi $\mathrm{P}$ yaitu $\left\{\mathrm{n}_{1}, \mathrm{n}_{2}, \mathrm{n}_{\mathrm{P}}\right\}$. Oleh karena itu proses pengukuran dapat dinyatakan dengan model matrik $\Phi$, yaitu:

$$
\boldsymbol{y}=\boldsymbol{\phi} \boldsymbol{\gamma}^{-1} \boldsymbol{F}=\boldsymbol{A F}
$$

Dimana A merupakan matrik $C S$ yang menyatakan matrik invers transformasi fourier yang diperoleh dengan menghilangkan baris dari $\gamma^{-1}$ yang sesuai dengan posisi sampel yang tidak tersedia, sehingga:

$$
\begin{aligned}
& \text { A } \\
& =\left[\begin{array}{cccc}
\psi_{0}\left(n_{1}\right) & \psi_{1}\left(n_{1}\right) & \ldots & \psi_{N-1}\left(n_{1}\right. \\
\psi_{0}\left(n_{1}\right) & \psi_{1}\left(n_{2}\right) & \ldots & \psi_{N-1}\left(n_{1}\right. \\
\vdots & \vdots & \ddots & \vdots \\
\psi_{0}\left(n_{M}\right) & \psi_{1}\left(n_{M}\right) & \ldots & \psi_{N-1}\left(n_{1}\right.
\end{array}\right.
\end{aligned}
$$

Dimana fungsi basis fourier adalah :

$$
\psi_{k}(n)=e^{j 2 \pi k n / N}
$$

Sehingga perumusan masalah Compressive Sensing dapat dinyatakan menjadi:

$$
\begin{array}{cc}
\min \|F\|_{1} \\
\text { s.t. } y=A F
\end{array}
$$

\section{HASIL DAN SIMULASI}

Secara umum, representasi pada domain waktu untuk sebagian besar sinyal mempunyai tingkat kejarangan sinyal yang rendah. Untuk itu, sinyal-sinyal ini bukan sinyal yang sebenarnya tetapi representasi mereka di bawah dasar tertentu adalah jarang atau kompresibel.

Pada gambar 2 ditampilkan beberapa hasil dari simulasi yang dilakukan, dimana sinyal yang diolah menggunakan metode $C S$ merupakan sinyal yang sudah dalam representasi jarang (sparse) dalam domain waktu. Dari 1024 sampel data yang digunakan pada domain waktu tersebut dengan 6 puncak yang bukannol, diambil hanya 256 sampel dengan menggunakan pengukuran gaussian random. Dari gambar 2 bagian c dapat dilihat bahwa dengan mengaplikasikan algoritma pemulihan $C S$, sinyal dapat dikembalikan atau dipulihkan kembali seperti sinyal asli. 

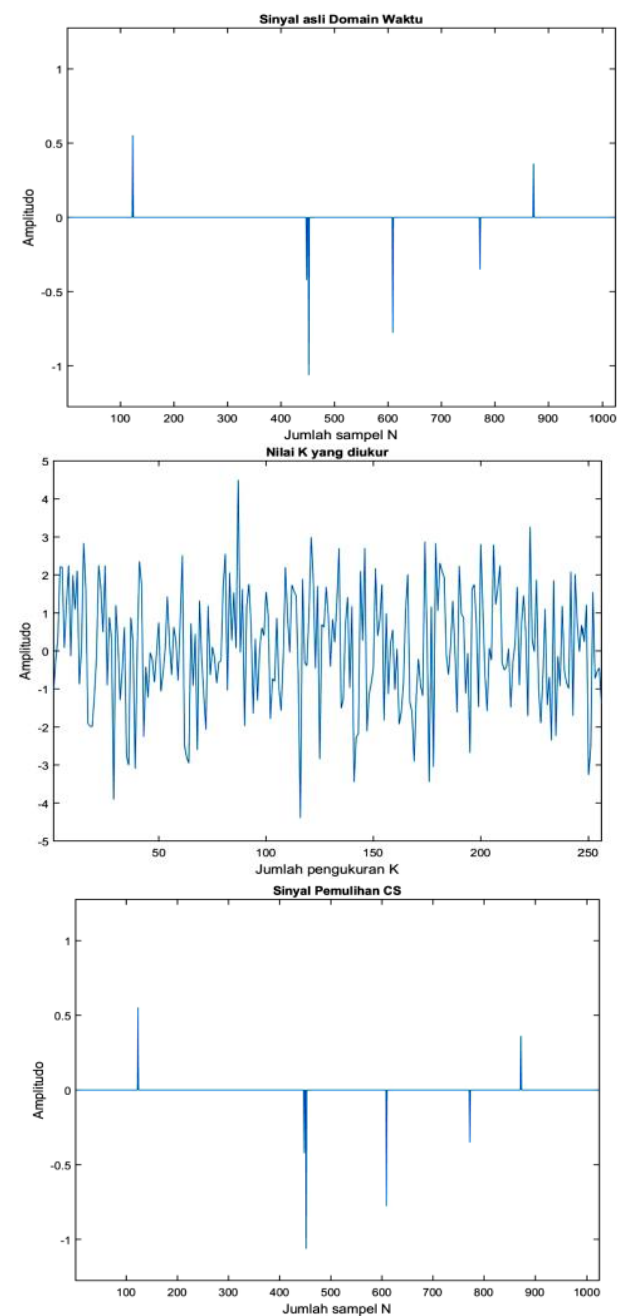

Gbr.2 a. Sinyal asli domain waktu, b. jumlah sampel K pengukuran, c. Sinyal Pemulihan $C S$

Pada Gambar 3, dapat diketahui bahwa sinyal yang secara kasat mata terlihat mirip sekali, namun setelah diukur kedekatan sinyal tersebut terdapat perbedaan walaupun sangat kecil sekali dalam ukuran $10^{-4}$.

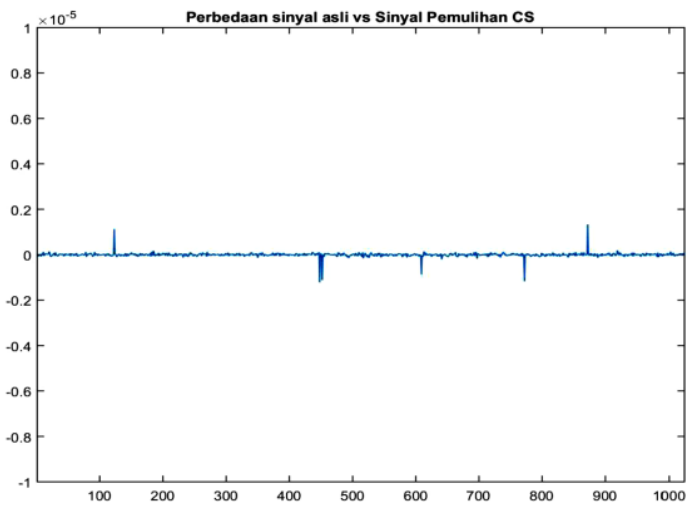

Gbr.3 Perbedaan antara Sinyal pemulihan CS dengan sinyal asli domain waktu
Pada Gambar 4, digunakan sinyal dalam domain waktu yang belum merupakan sinyal yang jarang.

Pada simulasi ini jumlah sampel pengukuran sebanyak 256 sampel dari 1024 panjang sampel dan dengan 7 puncak bukannol. Kemudian diterapkan tranformasi $D F T$ dan transformasi $D C T$ pada sinyal asli tersebut untuk mendapatkan sinyal jarang dan dengan algoritma pemilihan random sinyal tersebut dilakukan optimisasi.

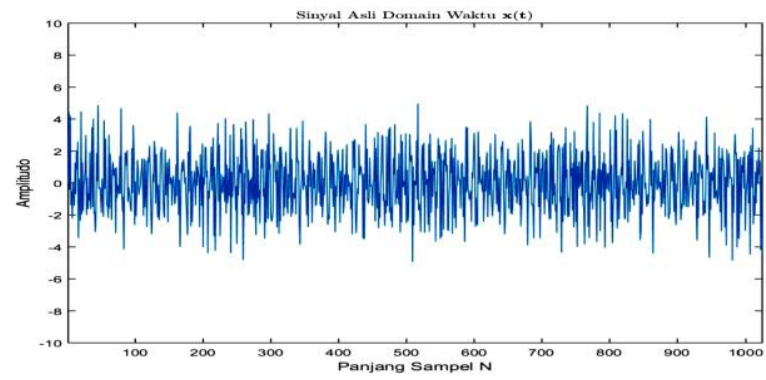

a.

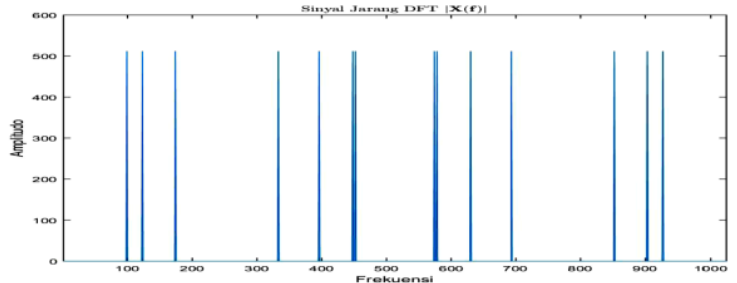

b.

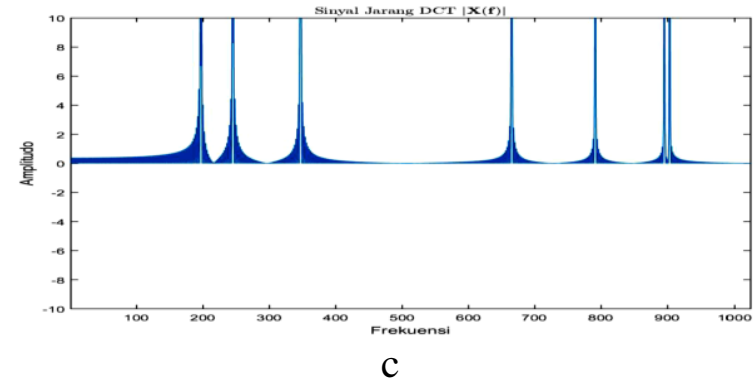

Gbr.4 a. Sinyal Asli domain waktu b. Sinyal Jarang DFT c. Sinyal jarang DCT

Pada gambar 5 dapat dilihat bahwa dari sinyal yang asli dalam domain waktu dengan menerapkan algoritma Compressive Sensing, sinyal dapat dipulihkan kembali dengan cukup baik walaupun masih terdapat sedikit selisihnya. 


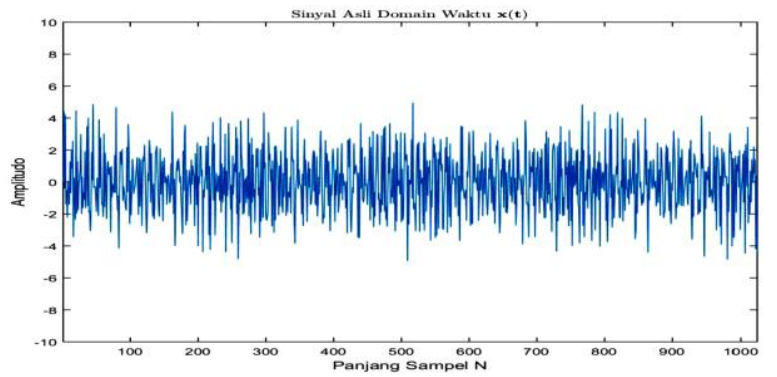

a.

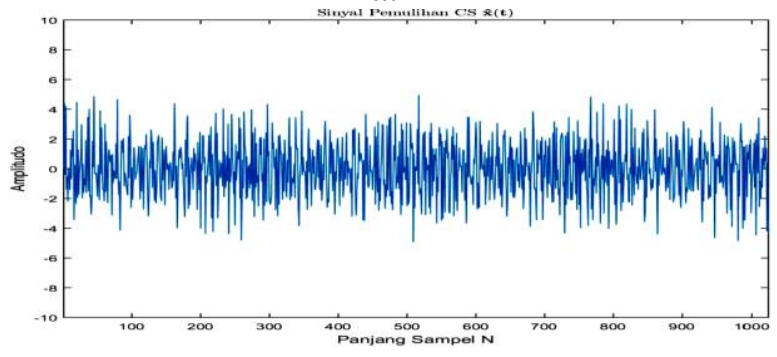

b.

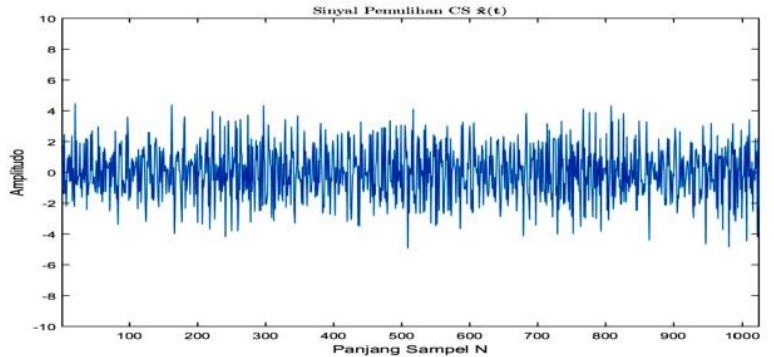

c.

Gbr.5 a. Sinyal Asli domain waktu b. Sinyal Pemulihan CS dengan transformasi DFT, c. Sinyal Pemulihan dengan Transformasi $D C T$

Antara sinyal asli dengan sinyal hasil pemulihan Compressive Sensing didapatkan perbedaan yang dapat dilihat pada gambar 6 dan gambar 7, yang masing-masing diterapkan jenis transformasi yang berbeda yaitu $D F T$ dan $D C T$. Dan dapat dilihat bahwa dari kedua gambar tersebut, yang menggunakan transformasi DFT memiliki nilai perbedaan yang cukup kecil dibandingkan dengan sinyal jarang yang diperoleh dari transformasi $D C T$.

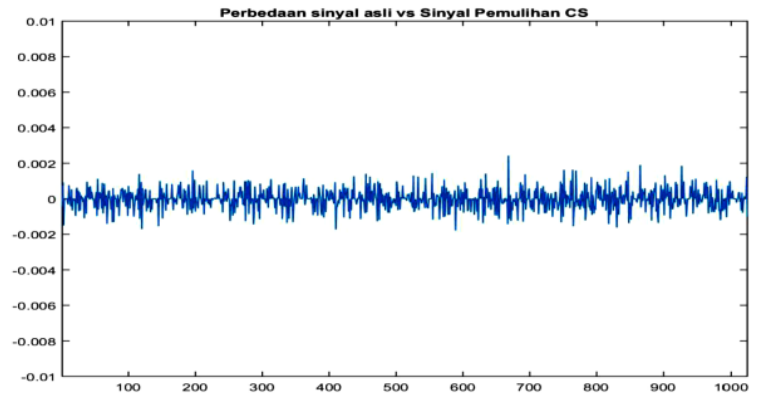

Gbr.6 Perbedaan sinyal asli dengan sinyal hasil pemulihan CS pada transformasi DFT

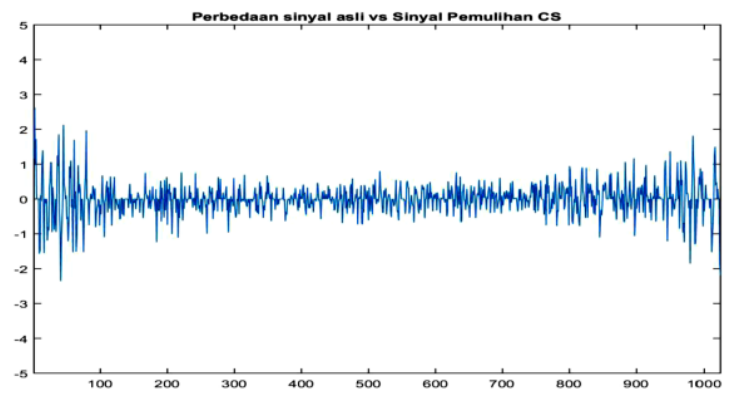

Gbr.7 Perbedaan sinyal asli dengan sinyal hasil pemulihan CS pada transformasi DCT

\section{KESIMPULAN}

Pemulihan sinyal dapat diperoleh hanya dengan sejumlah kecil sampel pengukuran menggunakan Compressive Sensing. Pada makalah ini, Compressive Sensing memberikan hasil yang cukup baik dalam memulihkan sinyal yang memiliki sifat kejarangan dan inkoheren. Dari simulasi $C S$ pada sinyal waktu diskrit, dengan penerapan algoritma ll-norm namun dengan transformasi yang berbeda, didapatkan bahwa cenderung yang menggunakan transformasi DFT memberikan error selisih yang cukup kecil.

\section{REFERENSI}

[1]. E.. Candes, J. Romberg, and T. Tao, "Robust uncertainty principles: Exact signal reconstruction from highly incomplete frequency information," IEEE Trans. Information Theory, vol. 52, no. 2, pp. 489-509, February 2006.

[2]. D. L. Donoho, "Compressed sensing," IEEE Trans. Inform. Theory, vol. 52, pp. 1289-1306, July 2006.

[3]. E. Candes and M. Wakin, "An introduction to compressive sampling," IEEE Signal Processing Magazine, vol. 25, no. 2, pp. 21-30, March 2008.

[4]. Amin Tavakoli and Ali Pourmohammad, Member, IACSIT proposed an approach of "Image Denoising Based On Compressing Sensing",2012.

[5]. E. Candes, J. Romberg, "ll-magic: Recovery of Sparse Signals via Convex Programming", October 2005. 
[6]. Y. Eldar and G. Kutyniok, Compressive Sensing Theory and Applications,

Cambridge University Press, 2012.

[7]. S. Foucart and H. Rauhut, A

Mathematical Introduction to

Compressive Sensing, Springer,

New York, NY, USA, 2013.

[8]. E. J. Candès and T. Tao, "Decoding by linear programming," IEEE

Transactions on Information Theory, vol. 51, no. 12, pp. 4203-4215, 2005.

[9]. E. J. Candès, J. Romberg, and T. Tao, "Robust uncertainty principles: exact signal reconstruction from highly incomplete frequency information," IEEE Transactions on Information Theory, vol. 52, no. 2, pp. 489-509, 2006.

[10]. S. G. Mallat and Z. Zhang, "Matching pursuits with time-frequency dictionaries," IEEE Transactions on Signal Processing, vol. 41, no. 12, pp. 3397-3415, 1993.

[11]. Yanfeng. Z, at all, Conjugate Gradient Hard Thresholding Pursuit Algorithm for Sparse Signal Recovery, journal MDPI, Alghorithms, Published: 13 February 2019. 